\title{
Review
}

\section{Now or never: what will it take to save the Sumatran rhinoceros Dicerorhinus sumatrensis from extinction?}

\author{
A b d ul Wahab Ahmad Zafir, Junaidi Payne, Azlan Mohamed, Ching Fong \\ Lau, Dionysius Shankar Kumar Sharma, Raymond Alfred \\ Amirtharaj Christy Williams, Senthival Nathan, Widodo S. Ramono and \\ Gopalas a my Reuben Clements
}

\begin{abstract}
In 1994 Alan Rabinowitz decried what he regarded as lackadaisical attempts by governments, NGOs and international funding agencies to conserve the Sumatran rhinoceros Dicerorhinus sumatrensis. Sixteen years on it is timely to evaluate whether his warnings were heeded. We review the current conservation status of $D$. sumatrensis throughout its range and the latest threats and challenges complicating efforts to conserve this species. Recent data from governments, NGOs and researchers indicate that the global population could be as low as 216 , a decline from c. 320 estimated in 1995. Based on lessons learnt and expert opinions we call on decision makers to focus on two core strategies for conservation of D. sumatrensis: (1) the translocation of wild individuals from existing small, isolated or threatened forest patches into semi-in situ captive breeding programmes, and (2) a concomitant enhancement of protection and monitoring capacities in priority areas that have established these breeding facilities or have recorded relatively high population estimates and track encounter rates. At least USD 1.2 million is required to implement these strategies annually in four priority areas: Bukit Barisan Selatan and Way Kambas National Parks on Sumatra, and Danum Valley Conservation Area and Tabin Wildlife Re-
\end{abstract}

\footnotetext{
Abdul Wahab Ahmad ZafiR* (Corresponding author), Azlan Mohamed, Ching Fong Lau and Dionysius Shankar Kumar Sharma WWFMalaysia, Petaling Jaya, Selangor, Malaysia. E-mail ahmad.zafir@gmail.com

Junaidi Payne ${ }^{\dagger}$ and Raymond Alfred WWF-Malaysia, Kota Kinabalu, Sabah, Malaysia

Amirtharaj Christy Williams WWF-Nepal, Kathmandu, Nepal

Senthival Nathan Sabah Wildlife Department, Kota Kinabalu, Sabah, Malaysia

Widodo S. RAmono Yayasan Badak Indonesia, Bogor, Indonesia

Gopalasamy Reuben Clements School of Marine and Tropical Biology, James Cook University, Cairns, Queensland, Australia, and Center for Malaysian Indigenous Studies, Universiti Malaya, Kuala Lumpur, Malaysia

${ }^{*}$ Current address: School of Biological Science, Universiti Sains Malaysia, Penang, Malaysia

${ }^{\dagger}$ Current address: Borneo Rhino Alliance, c/o Institute for Tropical Biology and Conservation, Universiti Malaysia Sabah, Kota Kinabalu, Sabah, Malaysia

Received 15 April 2010. Revision requested 20 May 2010.

Accepted 1 July 2010.
}

serve on Sabah. Given that conservation funds are rarely secure and D. sumatrensis is still in decline we call on potential donors to help secure and augment existing capacities of organizations in these four priority areas before committing resources to elucidate the status of the species in other areas such as Gunung Leuser and Taman Negara National Parks.

Keywords Borneo, captive breeding, Dicerorhinus sumatrensis, Indonesia, Malaysia, poaching, rhinoceros, Sumatra

\section{Introduction}

$\mathrm{O}$ nce distributed throughout South-east Asia to the foothills of the Himalayas (Corbett \& Hill, 1992), the Sumatran rhinoceros Dicerorhinus sumatrensis is now confined to isolated parts of Indonesia and Malaysia: D. sumatrensis sumatrensis is confined to Sumatra and Peninsular Malaysia and D. sumatrensis harrissoni is endemic to Borneo. In 1995 the estimate of the total number of D. sumatrensis in these range states was c. 320 (Table 1 ). There may be $<250$ mature individuals globally and the species is categorized as Critically Endangered on the IUCN Red List (IUCN, 2010). However, researchers and NGOs involved in monitoring and protection indicate there may only be c. 216 wild individuals remaining (Table 1). Even this estimate is contentious given the species' patchy distribution and secretive nature (Payne, 1990) coupled with the lack of reliable and comparable field data.

Sixteen years ago Rabinowitz (1994) claimed that much of the resources for the conservation of D. sumatrensis went into politically favourable initiatives that did not mitigate the real threats responsible for the species' decline: habitat loss and poaching. It is disconcerting that even after Rabinowitz (1994) chastised the international conservation community for not doing enough to address the species' plight, its population remains perilously low 16 years on. Here, we review the conservation status of D. sumatrensis across its range states and the threats facing the species. We call on conservation NGOs and governments of range states 
TABLE 1 Summary information for Sumatran rhinoceros Dicerorhinus sumatrensis populations from government agencies, researchers and NGOs in Sumatra, Peninsular Malaysia and Sabah.

\begin{tabular}{|c|c|c|c|}
\hline Area & $\begin{array}{l}\text { Population estimates } \\
\text { provided by range } \\
\text { states in } 1995 \\
\text { (Foose \& van } \\
\text { Strien, 1997) }\end{array}$ & $\begin{array}{l}\text { Latest population } \\
\text { [occupancy }^{1} \text { ] } \\
\text { estimates (source) }\end{array}$ & $\begin{array}{l}\text { Latest no. of tracks } \\
\text { per } 100 \mathrm{~km} \\
\text { [SE if known]; survey } \\
\text { distance }(\mathrm{km}) \text {; survey } \\
\text { dates (source) }\end{array}$ \\
\hline \multicolumn{4}{|l|}{ Sumatra } \\
\hline $\begin{array}{l}\text { Gunung Leuser } \\
\text { National Park }\end{array}$ & 60 & 60-80 (MOF, 2007) & \\
\hline $\begin{array}{l}\text { Bukit Barisan Selatan } \\
\text { National Park }\end{array}$ & 22 & $\begin{array}{l}\text { 50-70 [0.32] (WCS, YABI and } \\
\text { BBSNP in Talukdar et al., 2009) }\end{array}$ & $\begin{array}{l}4.62 ; 2,532 ; 2005-2006 \\
\text { (Isnan et al., 2006) }\end{array}$ \\
\hline Way Kambas National Park & 16 & $\begin{array}{l}27-33[0.43] \text { (PKHS, WCS, YABI } \\
\text { and WKNP in Talukdar et al., 2009) }\end{array}$ & $\begin{array}{l}\text { 4.46; 2,756; } 2006 \\
\text { (Isnan et al., 2006) }\end{array}$ \\
\hline Kerinci Seblat National Park & 28 & Extinct (MOF, 2007) & \\
\hline Others & 25 & 10-15 (MOF, 2007) & \\
\hline Subtotal & 151 & $147-198$ & \\
\hline \multicolumn{4}{|l|}{ Peninsular Malaysia } \\
\hline Taman Negara National Park & 44 & 21-34 (DWNP, 2005) & $\begin{array}{l}0.42 \text { [0.24]; 718; 1999-2001 } \\
(\text { Kawanishi \& Sunquist, 2004) }\end{array}$ \\
\hline Royal Belum State Park & 10 & 12-13 (DWNP, 2005) & $\begin{array}{l}0.14[0.14] ; 710 \\
2007-2010(\mathrm{WWF}- \\
\text { Malaysia, unpubl. data) }\end{array}$ \\
\hline Endau Rompin National Park & 9 & 1-2 (DWNP, 2005) & $\begin{array}{l}0 ; 2,500 ; 2008-2010 \\
\text { (WCS, Malaysia Program) }^{2}\end{array}$ \\
\hline Others & 36 & 35-45 (DWNP, 2005) & \\
\hline \multicolumn{4}{|l|}{ Sabah } \\
\hline $\begin{array}{l}\text { Danum Valley Conservation } \\
\text { Area }\end{array}$ & 11 & $\begin{array}{l}\text { 13-15 (Alfred \& Payne, 2005; } \\
\text { Talukdar et al., 2009) }\end{array}$ & $\begin{array}{l}\text { 4.99; 621; 2005-2010 } \\
\text { (WWF-Malaysia, } \\
\text { unpubl. data) }\end{array}$ \\
\hline Tabin Wildlife Reserve & 20 & $\begin{array}{l}15 \text { (BORA \& SOS Rhino in } \\
\text { Talukdar et al., 2009) }\end{array}$ & \\
\hline Others & 39 & 7 (Talukdar et al., 2009) & \\
\hline Subtotal & 70 & 37 & \\
\hline Total & 320 & $216-284$ & \\
\hline
\end{tabular}

${ }^{1}$ Occupancy refers to the proportion of an area that is occupied by D. sumatrensis

${ }^{2}$ Extremely low track encounter rates do not appear concordant with latest population estimates

to focus on two core strategies, for which we provide estimates of the annual implementation cost. This turns out to be a relatively small price to pay for saving a Critically Endangered species.

\section{Conservation status}

\section{Sumatra}

D. sumatrensis formerly occurred in all eight provinces of the Indonesian island of Sumatra (van Strien, 1974) but now remains in only three (Aceh, Lampung and South Sumatra). Eight populations have been extirpated over the last 15 years including that in Kerinci Seblat National Park (Uryu et al., 2010; Fig. 1), which once comprised 28 individuals (Foose \& van Strien, 1997). According to the Ministry of Forestry (MOF, 2007) current island-wide population estimates are 145-200 and the species mainly persists in three protected areas: Gunung Leuser, Bukit Barisan Selatan and Way Kambas National Parks (Fig. 1, Table 1). However, reports suggest that the Gunung Leuser population, which was the best studied in Sumatra (van Strien, 1985), could now be much lower, although there is little information on its status (W.S. Ramono, pers. obs.). The species persists in Bukit Barisan Selatan and Way Kambas National Parks, with reasonably high track encounter rates and photo-captures. Kinnaird et al. (2003) obtained 10 photo-captures of D. sumatrensis from 4,967 trap days in $140 \mathrm{~km}^{2}$ in Bukit Barisan Selatan National Park even though their surveys were not targeting the species. Despite habitat loss from fires and expanding coffee plantations in and around this Park (Kinnaird et al., 2003), monitoring and enforcement efforts by government-backed Rhino Protection Units have helped maintain what is one of Sumatra's largest populations of D. sumatrensis. In Way Kambas, where a relatively smaller population is being 


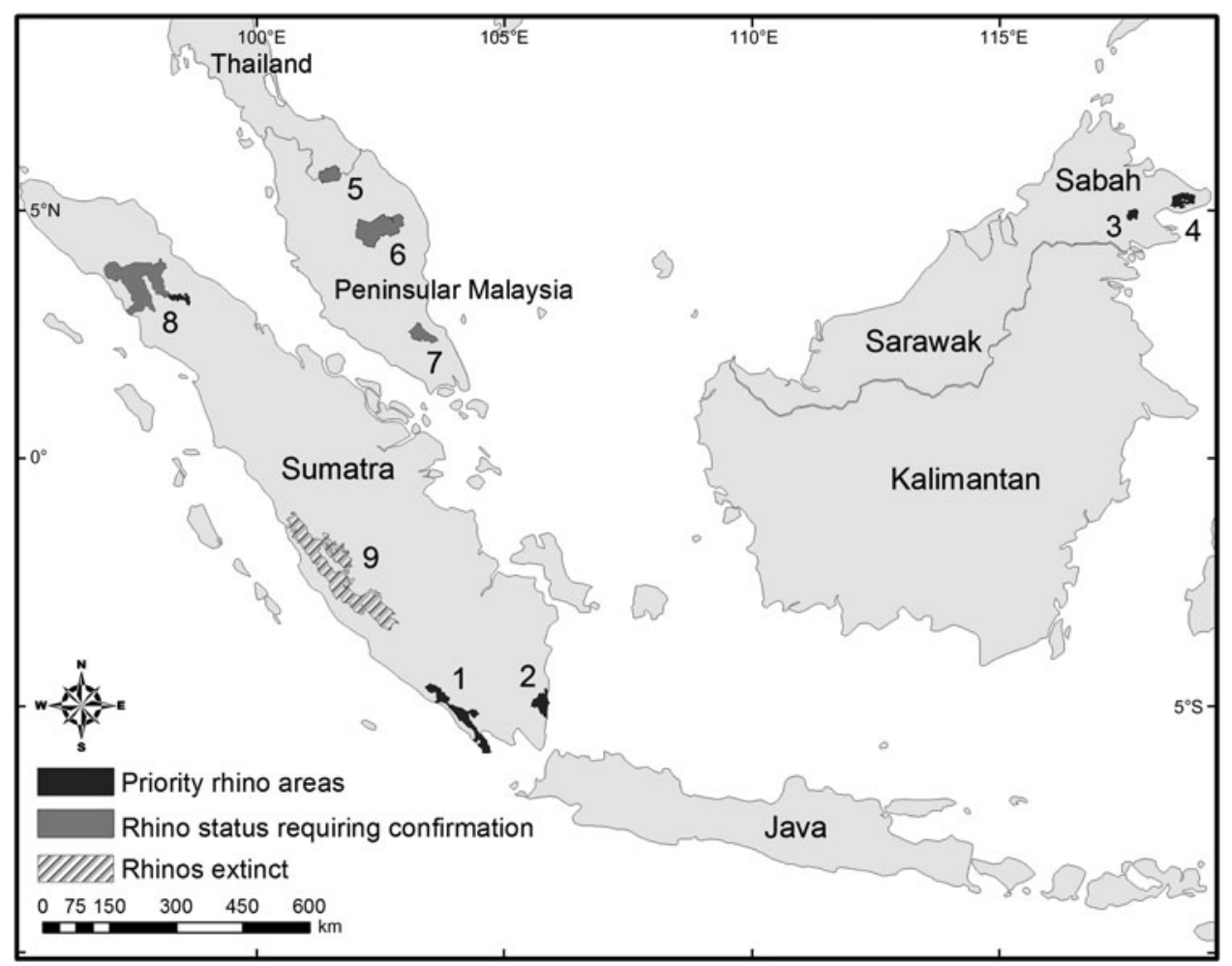

FIG. 1 Priority Sumatran rhinoceros Dicerorhinus sumatrensis areas: 1, Bukit Barisan Selatan National Park; 2, Way Kambas National Park; 3, Danum Valley Conservation Area; 4, Tabin Wildlife Reserve. Areas identified by the IUCN Asian Rhino Specialist Group (AsRSG) as requiring scientifically defensible population estimates to confirm conservation status: 5, Royal Belum State Park; 6, Taman Negara National Park; 7, Endau Rompin National Park; 8, Gunung Leuser National Park. Area identified by the AsRSG where D. sumatrensis has been extirpated: 9, Kerinci Seblat National Park.

protected, a semi-in situ breeding centre for D. sumatrensis was established in 1998 as a last-ditch attempt to save the Indonesian population from extinction.

\section{Peninsular Malaysia}

The Malay Peninsula probably provides the last hope for D. sumatrensis on mainland South-east Asia in terms of habitat availability, yet the species' viability and conservation status remains uncertain because of extremely low densities and a paucity of reliable population estimates (Clements et al., 2010). Low numbers and declining population trends have been reported since the $1930 \mathrm{~s}$ (Hubback, 1939) and, up to 1994, estimates of the population have varied between 10 and 130 (Metcalfe, 1961; Stevens, 1968; Mohd. Khan et al., 1982; Mohd. Khan, 1987, 1989). Subsequently, Zainal Zahari (1995) reported a drastic decline from 77-130 individuals in 1993 to c. 28-30. Since then population estimates from the Department of Wildlife and National Parks (DWNP) have continued to fluctuate, with the latest published figure being 69-94 (Table 1). However, the survey techniques used to derive these estimates are unknown and since 1994 no further individuals have been physically captured and no sightings have been documented (Tan, 2003).
We focus our summary on three of Peninsula Malaysia's largest protected areas, which are considered priority areas for conservation of D. sumatrensis (Foose \& van Strien, 1997): Taman Negara, Endau Rompin National Park and Royal Belum State Park (Fig. 1, Table 1). Taman Negara, which is the country's largest protected area, was regarded as one of Malaysia's strongholds for D. sumatrensis (Flynn \& Abdullah, 1984). Surveys by Kawanishi \& Sunquist (2004), which were the most scientifically robust large mammal surveys in this Park so far, covered c. $15 \%\left(600 \mathrm{~km}^{2}\right)$ of the Park and yielded 4,533 wildlife photos from 14,054 trap nights across forests overlapping the species' known altitudinal range. However, there were no photo-captures of D. sumatrensis. Track encounter rates were also relatively low (Table 1) compared to six other large ungulate species recorded in the same study. Although not targeting D. sumatrensis specifically, these surveys suggest an extremely small population in Taman Negara (Kawanishi et al., 2003) inconsistent with it purportedly having the largest D. sumatrensis population in Peninsular Malaysia (Foose \& van Strien, 1997). In Endau Rompin National Park 20-25 individuals were estimated to be present in the 1980s (Flynn \& Abdullah, 1984) but surveys in the 1990 s failed to detect fresh tracks and found numerous signs of poaching (M.T. Abdullah, pers. comm.). Since 2008 tiger prey occupancy 
surveys conducted by the Wildlife Conservation Society (Malaysia) in this Park have yet to detect signs of D. sumatrensis along transects totalling more than $2,500 \mathrm{~km}$ (M. Gumal, pers. comm.).

Royal Belum State Park, which was identified as another protected area with viable populations (IUCN, 1997), has yielded similar results. Since February 2007 extensive surveys have been conducted in suitable habitats (e.g. major rivers, valleys, salt licks, old wallows and ridges) and localities where indigenous people claimed to have seen D. sumatrensis recently but only one possible footprint has been detected. To date, camera-trapping surveys have not photo-captured D. sumatrensis despite yielding 2,124 wildlife photos over 844 trap nights and track encounter rates are extremely low (Table 1). In interviews with 297 people frequently entering forests (indigenous communities, hunters, loggers and villagers extracting forest products) only $2 \%$ of interviewees claimed to have seen D. sumatrensis within the last 5 years. In addition, no active rhinoceros wallows have been recorded in the Park since intensive surveys began in 2007 .

\section{Sabah}

When the distribution of D. sumatrensis in Sabah was reviewed in the 1990s (Payne, 1990; Boonratana, 1997; Foose \& van Strien, 1997) the population was estimated to be c. 40-70 (Table 1). Danum Valley Conservation Area $\left(438 \mathrm{~km}^{2}\right)$ and Tabin Wildlife Reserve $\left(1,225 \mathrm{~km}^{2}\right)$ now support the State's largest D. sumatrensis populations (Fig. 1, Table 1). Track encounter rates in monitoring surveys in Danum have been comparable to those of protected areas in Sumatra with sizeable D. sumatrensis populations (Table 1). In Tabin surveys over the past 3 decades involved simultaneous sweeps to estimate the size of the population (which is similar to Danum's) but systematic surveys have been difficult to implement because of the rugged terrain, frequent heavy rain and insufficient field capacity (J. Payne, pers. obs.). Apart from these strongholds, other sites across Sabah (whose localities remain undisclosed for security reasons) still support isolated individuals. One of these isolated individuals was spotted in an oil palm plantation adjacent to a forest patch and was subsequently rescued and translocated to Tabin (NST, 2008). Although populations in Sabah have not shown any signs of increase (c. 37 individuals; Table 1), evidence of breeding in the form of fresh footprints of immature individuals was recorded in both Danum and Tabin in 2006.

\section{Threats and challenges}

Prior to 1950 numbers of D. sumatrensis were probably already low as there were major gaps in the species' distribution in apparently suitable habitats (Hubback,
1939). The species is now probably confined to protected lowland forests or high-altitude forests that are largely inaccessible to conversion. Therefore, habitat loss, especially in the lowlands, is no longer the most significant threat to the conservation of the species in Sumatra (Uryu et al., 2010) and Malaysia.

The small population size is now the most significant threat to the species. Various factors associated with very low numbers (e.g. narrow genetic base, difficulty in finding a fertile mate) are likely to drive populations to the point where death rates will exceed birth rates even with suitable habitat and zero offtake (Courchamp et al., 2008). Rhinoceroses have a long inter-birth interval and small increases in juvenile mortality can suppress recruitment rates below levels needed to replace breeding adults (Johnson, 2006; Cranbrook, 2009). The only information on the inter-birth interval of D. sumatrensis comes from Cincinnati Zoo where calves have been born at 34-month intervals (Foose, 2006; T. Roth, pers. comm.). In the wild birth intervals are likely to have grown further apart, especially as the probability of males meeting receptive females decreased. If Danum and Tabin protected areas are each assumed to contain 15 individuals, that c. $50 \%$ are females, and that some of these are too old or too young to reproduce, only three or four individuals are likely to be reproductively active in each site. With a birth interval of 3 years under optimum wild conditions, a maximum of only one D. sumatrensis will be born into each population annually. Furthermore, at least half of all the females caught between 1984 and 1995 in Sumatra, Peninsular Malaysia and Sabah had reproductive tract pathology (Schaffer et al., 2001), a phenomenon associated with no pregnancies, which reflects a lack of breeding opportunities. Another consequence of low population sizes is an increased likelihood of skewed sex ratios, a phenomenon revealed during trapping operations in the 1980 s and 1990s. Of 10 D. sumatrensis captured in Sabah between March 1987 and November 1995 eight were mature males; because females are potentially easier to locate than males because of their smaller home ranges, the females may have been selectively taken by poachers.

Poaching is the second significant risk to the survival of D. sumatrensis, although it was the primary threat in the early 2oth century (Hubback, 1939; Medway, 1977). Rabinowitz (1994) similarly identified poaching (for horns, hooves and other body parts for traditional Chinese medicine) and habitat loss as the two main drivers of the species' decline. In Sumatra the government reported that poaching was brought under control after 1997 (MOF, 2007). In Bukit Barisan Selatan and Way Kambas National Parks, however, anti-poaching data revealed that D. sumatrensis was still being targeted during 2002-2009 (Table 2). Eight populations went extinct during 1997-2007 (Uryu et al., 2010). In Peninsular Malaysia, DWNP (2006) estimated that c. 30 individuals were poached during 1975-2005; horns from at 
TABle 2 Anti-poaching statistics from the Rhino Protection Unit in Bukit Barisan Selatan (BBS) and Way Kambas (WK) National Parks, Sumatra, Indonesia, for 2002-2009.

\begin{tabular}{lclll}
\hline & $\begin{array}{l}\text { Poachers } \\
\text { arrested } \\
\text { in BBS }\end{array}$ & $\begin{array}{l}\text { Poachers } \\
\text { arrested } \\
\text { in WK }\end{array}$ & $\begin{array}{l}\text { Snares/traps } \\
\text { removed } \\
\text { in BBS }\end{array}$ & $\begin{array}{l}\text { Snares/traps } \\
\text { removed } \\
\text { in WK }\end{array}$ \\
\hline 2002 & $5^{\star}$ & & & \\
2003 & $14^{*}$ & & & \\
2004 & $11^{\star}$ & 4 & & \\
2005 & 1 & 11 & 10 & \\
2006 & 4 & 4 & 22 & $322^{\star}$ \\
2007 & 5 & 2 & $1^{\star}$ & $62^{\star}$ \\
2008 & 0 & 3 & $3^{*}$ & 6 \\
2009 & 4 & 4 & 6 & \\
\hline
\end{tabular}

${ }^{\star}$ Indicates some targeted rhinoceroses (source: Yayasan Badak Indonesia, unpubl. data)

least eight individuals and a piece of skin were discovered in pharmacies in the states of Penang and Johor, respectively (DWNP, 2005). The world's largest wildlife trader was still trading horns of D. sumatrensis after 1995 (Christy, 2010). Interviews with hunters during 2007-2008 in Peninsular Malaysia indicated that there was still a demand for rhinoceros horns (TRAFFIC, unpubl. data), which can fetch up to USD 45,000 $\mathrm{kg}^{-1}$. Dinerstein (2003) reported that Asian rhinoceros horn could be sold for USD $30,000 \mathrm{~kg}^{-1}$, triple the mean price for that of the African rhinoceros Diceros bicornis (USD $10,000 \mathrm{~kg}^{-1}$ ).

\section{Two core conservation strategies}

Maguire et al. (1987) suggested several measures to save D. sumatrensis from extinction (anti-poaching efforts, fencing, translocation and captive breeding). These mitigation measures have been implemented with varying degrees of success and failure over the last 16 years in Indonesia, Malaysia and the USA. We believe only two of these measures are relevant to ensure the survival of the species.

\section{Translocate isolated individuals into semi-in situ captive breeding programmes}

Mohd. Khan (1989) suggested that c. 50 individuals could sustain 5-10 generations of the the Sumatran rhinoceros, whereas a recent meta-analysis showed that any mammal species generally requires a minimum of 3,876 individuals to maintain population viability (Traill et al., 2007). Current Sumatran rhinoceros populations number less than these thresholds and in some areas only isolated individuals remain. While in situ captive breeding programmes could theoretically help augment wild populations via reintroductions, Rabinowitz (1994) was critical of the magnitude of resources invested in these programmes and labelled them expensive failures; 42 D. sumatrensis were caught for this purpose and 34 died during 1984-2006 (Foose, 2006). Captive breeding programmes have suffered significantly more setbacks than successes but we argue that some form of captive breeding is still necessary. Without specific actions to bring Sumatran rhinoceroses together to boost production it is likely that the species will go extinct even if protection of suitable habitat increases. Only 10 individuals remain in captivity (AP, 2009) and successful births have only occurred in the Cincinnati Zoo. A female named Emi produced three calves at the zoo, the youngest of which was the first Sumatran rhinoceros bred and born in captivity since 1889 . However, Emi died in 2009 at c. 21 years; her eggs were rescued for possible in-vitro fertilization (AP, 2009).

Captive D. sumatrensis held in their range states require forest habitats and natural conditions to improve chances of breeding, and carefully managed captive breeding centres in native habitats (semi-in situ captive breeding) were deemed necessary almost a decade ago (van Strien, 2001). We still concur with van Strien's recommendation despite the absence of reproductive success so far. Three breeding facilities were created to receive translocated D. sumatrensis: Way Kambas (Sumatra), Sungai Dusun (Peninsular Malaysia) and Sepilok (Sabah) but all three failed to breed the species. The latter two facilities no longer hold any living D. sumatrensis (Tan, 2003); an old female from Sepilok which was recently transferred to Tabin. The semi-in situ Sumatran Rhino Sanctuary in Way Kambas, however, is the most promising model for captive management. This sanctuary currently supports five $D$. sumatrensis and only one death, of an unproductive old female, has occurred. Constructed within the $1,250 \mathrm{~km}^{2}$ Way Kambas National Park in 1997 this sanctuary comprises 100 ha of forest habitat surrounded by an electrified fence. Circa 20 ha of forest habitat is provided for each individual (monitored continuously during daylight hours and breeding periods) and the design of the paddocks allows mixing and separation when necessary (Agil et al., 2002). D. sumatrensis were repatriated to this facility from zoos in January 1998 and they have adapted well (Anon., 2000). In 2007 the Sumatran Rhino Sanctuary received Andalas (the calf borne from Emi) to be paired with the resident females, two of which are young mature individuals brought to the Sanctuary after 2000. Andalas recently impregnated another female, Ratu, in the sanctuary (Hance, 2010a). This success is attributable not only to the natural settings of the sanctuary but also to the use of monitoring techniques (e.g. hormonal assays and ultrasound techniques) initially introduced from Cincinnati Zoo to determine the optimal time for introducing males and females (IRF, 2010). Although Ratu lost her pregnancy a few months later, there is optimism for a successful birth as it was her first 
pregnancy; Emi had five failed pregnancies before she gave birth to Andalas (Hance, 2010b). Annual operating costs for the Sumatran Rhino Sanctuary are at least USD 184,724 (YABI, 2009).

Based on this model the Sabah government launched a rescue programme for $D$. sumatrensis in 2009 that endorses the establishment of a semi-in situ captive breeding facility within Tabin similar to the Way Kambas model of individual small paddocks within a large fenced forest area. This facility, the Borneo Rhino Sanctuary (Cheang, 2009), will function as a breeding area for reproductively isolated D. sumatrensis translocated from other sites. Borneo Rhino Alliance (BORA, 2010), a non-profit company, will continue the role of the now defunct SOS-Rhino Borneo to assist the Sabah government in the development and management of this sanctuary. The annual operating costs of this sanctuary, once fully established, could be at least USD 334,000, excluding costs of capture and translocation.

\section{Secure priority areas with enhanced monitoring capacities}

Rabinowitz (1994) lambasted the international conservation community for not providing enough resources to protect rhinoceroses in the wild. Anti-poaching patrols, which increase the chances of poachers being caught, are the greatest disincentive to hunting of $D$. bicornis in Africa (Milner-Gulland \& Leader-Williams, 1992), the full protection of which required one guard per $20 \mathrm{~km}^{2}$ of protected area. In April 1995 an anti-poaching initiative known as Conservation Strategy for Rhinos in South-east Asia (Indonesia and Malaysia) was organized. It received funding from the Global Environment Facility through the UN Development Programme. The Asian Rhino Specialist Group and International Rhino Foundation, which operated as the financial and administrative agent, jointly coordinated and facilitated this initiative (van Strien, 2001). The main objective was to establish units to protect and monitor D. sumatrensis populations, destroy snares and traps and arrest poachers in core D. sumatrensis areas (van Strien, 2001). In Peninsular Malaysia protection units have been in operation in key D. sumatrensis habitats since 1995 (Abdul Kadir, 2009). In Sumatra, eight and five protection units operate in Bukit Barisan Selatan and Way Kambas, respectively (Isnan et al., 2006).

Key features that set D. sumatrensis protection units in Indonesia apart from those in other regions include an intelligence and law enforcement unit to gather information on poacher identities, and that rangers from the Ministry of Forestry are seconded to the units to facilitate the arrest of suspected poachers. While the persistence of D. sumatrensis in Bukit Barisan Selatan and Way Kambas has been credited to intensive anti-poaching work by the protection units (MOF, 2007), their effectiveness has been difficult to evaluate. For example, the protection units in both areas reported an absence of poachers targeting D. sumatrensis since 2004 (Table 2) but this could be part of a trend associated with decreasing numbers of D. sumatrensis. Protection units were unable to prevent the extirpation of D. sumatrensis from Kerinci Seblat (Table 1). Additional data (e.g. number of snares removed each year in relation to law enforcement effort and occupancy estimates of $D$. sumatrensis, number of poaching cases detected by patrol- and intelligence-based efforts) need to be obtained to evaluate the effectiveness of enforcement interventions (Linkie et al. 2010). Nevertheless, more resources must be provided to improve existing law enforcement coverage and monitoring capacities if we want to determine the conservation status of D. sumatrensis in priority areas (Fig. 1). In Sumatra annual support for protection units and intelligence and law enforcement units operating in Bukit Barisan Selatan and Way Kambas (i.e. operational costs excluding technical, administrative and communication support; YABI, 2009) amounts to at least USD 397,423.

In Peninsular Malaysia protection units initiated by the federal government have focused their daily patrols in D. sumatrensis habitat within Taman Negara and have arrested 72 encroachers up to 2009 (Abdul Kadir, 2009). To our knowledge, however, only one person has ever been prosecuted for rhinoceros poaching in Peninsular Malaysia, in 1985 (Abdullah et al., 1989). However, the Malaysian government recently passed a new wildlife conservation law to be enforced in December 2010 (Kuppusamy, 2010); at least 13 new provisions are being suggested, including a significant enhancement of penalties for wildlife crimes involving protected species such as D. sumatrensis (e.g. fines of USD 30,000-150,000 coupled with mandatory prison sentences of up to 5 years). To complement the government's enforcement work NGOs initiated antipoaching units that patrol together with government agencies in D. sumatrensis habitat within Peninsular Malaysia and Sabah. In the former, WWF-Malaysia formed a wildlife protection unit to patrol in and around Royal Belum, a priority area identified by the Asian Rhino Specialist Group (Foose \& van Strien, 1997). In conjunction with government enforcement authorities the wildlife protection unit has removed 141 snares and apprehended 11 poachers since January 2009 (WWF-Malaysia, unpubl. data). However, no evidence of $D$. sumatrensis or poaching of the species was recorded by active patrols and intelligence networks during that period.

In Sabah both WWF-Malaysia and Borneo Rhino Alliance operate protection units for the populations in Danum, Tabin and other areas in the lower SegamaKinabatangan landscape. The Sabah State government granted the status of honorary wardens to some members of these protection units, who have powers of investigation and arrest. Given these enabling conditions, more resources 
need to be allocated to protect the two priority areas in Sabah by augmenting existing law enforcement coverage and the capacity to monitor effectiveness. Currently in Sabah annual financial support for protection units amounts to a total of USD 332,221: USD 111,221 at Danum (according to WWFMalaysia) and USD 216,000 at Tabin (according to Borneo Rhino Alliance), with protection unit staff also involved in care of captive D. sumatrensis and rescue work.

\section{Conclusions}

Some of Rabinowitz's (1994) warnings were heeded: protection of wild $D$. sumatrensis in some areas did increase and the removal of wild individuals into ex situ captive conditions soon ceased. Yet, since 1995, the population of D. sumatrensis appears to have declined by c. $32 \%$ to a lower bound estimate of c. 216 wild individuals. The prognosis for the survival of the species is not good and the situation will worsen unless there is more political support, better enforcement of wildlife laws, improved cooperation among stakeholders, and funds available to implement the two best available conservation strategies: (1) translocation of isolated wild $D$. sumatrensis into existing semi-in situ captive breeding programmes, to maximize reproductive success, and (2) securing priority areas (Bukit Barisan Selatan, Way Kambas, Danum and Tabin) with improved law enforcement coverage and monitoring capacities.

If decision makers in Indonesian and Malaysian governments do not commit to this approach we may never have another chance to reverse the decline of this species. Given that the remaining wild $D$. sumatrensis populations have not shown signs of recovery under the current funding scenario, potential donors could help strengthen the capacities of conservation agencies in the four priority areas, as well as support efforts to obtain scientifically defensible population estimates for other areas (e.g. Gunung Leuser and Taman Negara). The annual amount that is currently spent to sustain the bulk of conservation efforts for D. sumatrensis in the four priority areas is at least USD $1,245,368$, similar to the price of a 1939-edition Batman comic book auctioned off at Heritage Auctions of Dallas, Texas, USA in February 2010. Surely the future of the world's remaining Sumatran rhinoceroses is worth more than a piece of historical paraphernalia?

\section{Acknowledgements}

We dedicate this paper to Emi and N. van Strien. We are grateful to the governments of Indonesia and Malaysia, non-governmental conservation staff striving to keep the Sumatran rhinoceros alive (Program Konservasi Harimau Sumatera, WCS Indonesia Programme, WWF-Malaysia and WWF-Indonesia, Borneo Rhino Alliance, Yayasan Badak Indonesia), Universiti Malaysia Sabah for housing the Borneo Rhino Alliance, and donors (Sime Darby
Foundation, Honda [Malaysia] Sdn Bhd, WWF network offices, the International Rhino Foundation, US Fish \& Wildlife Service, and the Asian Rhino Project), all of whom are raising invaluable funds for conservation. We also thank Department of Wildlife and National Parks (Peninsular Malaysia), M.T. Abdullah, A. Campos-Arceiz, Suratman, W. Isnan, W.F. Laurance, W. Pusparini and A. Rubianto, for their helpful comments, and Matthew Linkie and an anonymous referee for their constructive reviews.

\section{References}

Abdul Kadir, H. (2009) Current status and threats of Sumatran rhinoceros (Dicerorhinus sumatrensis) in Peninsular Malaysia. In Report on the Meeting for Conservation of Sumatran and Javan Rhinos in South-East Asia (eds B.K. Talukdar, K. Crosbie, S. Ellis, W.S. Ramono, A.C. Williams \& Sectionov), p. 8. Asian Rhino Specialist Group, Guwahati, India.

Abdullah, M.T., Zainuddin, Z.Z. \& Suri, M.S.M. (1989) A review of the Sumatran Rhinoceros Conservation Programme and assessment of management alternatives for the future. In Proceedings of the International Conference on National Parks and Protected Areas, pp. 191-201. Department of Wildlife and National Parks, Kuala Lumpur, Malaysia.

Agil, M., Riyanto, M.A.C.T., Sumampau, T., Hodges, K. \& van Strien, N.J. (2002) A program of managed breeding for the Sumatran rhinoceros at the Sumatran rhino sanctuary, Way Kambas National Park, Indonesia. In Proceedings of the International Elephant and Rhino Research Symposium (eds H.M. Schwammer, T.J. Foose, M. Fouraker \& D. Olson), p. 303. Vienna, Austria.

Alfred, R. \& Payne, J. (2005) A Survey of the Eastern Sumatran Rhinoceros (Dicerorhinus sumatrensis harrissoni) in the Greater Danum Area, Sabah, 5-19 May 2005. WWF-Malaysia, Sabah Wildlife Department and Yayasan Sabah Group, Kota Kinabalu, Malaysia.

AnOn. (2000) Captive programs. Asian Rhino, 3, 14-18.

AP (Associated Press) (2009) Endangered Sumatran Rhino Dies at Cincinnati Zoo. Associated Press, 7 September 2009.

Boonratana, R. (1997) A Statewide Survey to Estimate the Distribution and Density of the Sumatran Rhinoceros, Asian Elephant and Banteng in Sabah, Malaysia. Wildlife Conservation Society, New York, USA.

BORA (Borneo Rhino Alliance) (2010) Http://www.borneorhinoalliance.org [accessed 24 October 2010].

Cheang, M. (2009) Reprieve for Rhinos. Http://thestar.com.my/ lifestyle/story.asp?file $=/ 2009 / 8 / 18 /$ lifefocus $/ 4387617 \&$ sec $=$ lifefocus [accessed 10 April 2010].

Christy, B. (2010) Asian Wildlife Trade: The Kingpin. Http:// ngm.nationalgeographic.com/2010/o1/asian-wildlife/christy-text [accessed 14 April 2010].

Clements, R., Darmarat, M.R., Ahmad Zafir, A.W., Venkataraman, A., Alfred, R., Payne, J. et al. (2010) Trio under threat: can we secure the future of rhinos, elephants and tigers in Malaysia? Biodiversity and Conservation, 9, 1115-1136.

Corbett, G.B. \& Hill, J.E. (1992) The Mammals of the Indomalayan Region: A Systematic Review. Oxford University Press, New York, USA.

Courchamp, F., Berec, L. \& Gascoigne, J. (2008) Allee Effects in Ecology and Conservation. Oxford University Press, New York, USA. 
Cranbrook, Earl of (2009) Late quaternary turnover of mammals in Borneo: the zooarchaeological record. Biodiversity and Conservation, 19, 373-391.

Dinerstein, E. (2003) The Return of the Unicorns: The Natural History and Conservation of the Greater One-horned Rhinoceros. Columbia University Press, New York, USA.

DWNP (Department of Wildlife and National Parks) (2005) Peninsular Malaysia-Sumatran Rhinoceros Conservation Action Plan 2005. Department of Wildlife and National Parks, Kuala Lumpur, Malaysia.

DWNP (Department of Wildlife and National Parks) (2006) Sumatran Rhinoceros Factsheet. Department of Wildlife and National Parks, Kuala Lumpur, Malaysia.

FlynN, R.W. \& Abdullah, M.T. (1984) Distribution and status of the Sumatran rhinoceros in Peninsular Malaysia. Biological Conservation, 28, 253-273.

Foose, T.J. (2006) International Studbook for Sumatran Rhino Dicerorhinus sumatrensis. International Rhino Foundation, Columbus, USA.

Foose, T.J. \& van Strien, N. (1997) Asian Rhinos: Status Survey Conservation Action Plan. IUCN, Gland, Switzerland, and Cambridge, UK.

Hance, J. (2010a) Pregnancy Gives New Hope for Rhino On-TheBrink of Extinction. Http://news.mongabay.com/2010/0218hance_sumrhino.html [accessed 14 April 2010].

Hance, J. (2010b) Sumatran Rhino Loses Pregnancy: Conservationists Saddened but Remain Resolute. Http://news.mongabay.com/2010/ 0331-hance_ratu.html [accessed 27 October 2010].

Hчвваск, T. (1939) The Asiatic two-horned rhinoceros. Journal of Mammalogy, 20, 1-20.

IRF (International Rhino Foundation) (2010) Rare Rhino Pregnancy Gives Hope to Species: Andalas-Ratu Love Story Proves Conservation Efforts Can Work. Http://www.rhinos-irf.org/andalasloves-ratu [accessed 14 April 2010].

Isnan, W.M., Subrata, D.D. \& van Strien, N.J. (2006) Annual Report 2006. Indonesian Rhino Conservation Program, Bogor, Indonesia.

IUCN (2010) IUCN Red List of Threatened Species v. 2010.1. IUCN, Gland, Switzerland. Http://www.iucnredlist.org [accessed 12 April 2010].

Johnson, C. (2006) Australia's Mammal Extinctions: A 50,00o Year History. Cambridge University Press, Cambridge, UK.

KAWANISHI, K. \& SUNQUist, M.E. (2004) Conservation status of tigers in a primary rainforest of Peninsular Malaysia. Biological Conservation, 120, 329-344.

Kawanishi, K., Sunquist, M.E. \& Abdul Malik, S. (2003) Rarity and possible new records of Sumatran rhinoceros in Taman Negara. Journal of Wildife and Parks, 20, 125-128.

Kinnaird, M.F., Sanderson, E.W., O'Brien, T.G., Wibisono, H.T. \& Woolmer, G. (2003) Deforestation trends in a tropical landscape and implications for endangered large mammals. Conservation Biology, 17, 245-257.

Kuppusamy, B. (2010) Tougher Wildlife Act not Enough, Say Activists. Http://www.ipsnews.net/news.asp?idnews $=52982$ [accessed 27 October 2010].

Linkie, M., Rood, E. \& S Sith, R.J. (2010) Modelling the effectiveness of enforcement strategies for avoiding tropical deforestation in Kerinci Seblat National Park, Sumatra. Biodiversity and Conservation, 19, 973-984.

Maguire, L.A., Seal, U.S. \& Brussard, P.F. (1987) Managing critically endangered species: the Sumatran rhino as a case study. In Viable Populations for Conservation (ed. M.E. Soule), pp. 141-158. Cambridge University Press, Cambridge, UK.
Medway, L. (1977) Mammals of Borneo: Field Keys and an Annotated Checklist. Monographs of the Malaysian Branch of the Royal Asiatic Society No. 7. Kuala Lumpur, Malaysia.

Metcalfe, G.T.C. (1961) Rhinoceros in Malaya and their future. In Nature Conservation in Malaya (eds J. Wyatt-Smith \& P.R. Whycherlry), pp. 183-193. Malayan Nature Society, Kuala Lumpur, Malaysia.

Milner-Gulland, E.J. \& Leader-Williams, N. (1992) A model of incentives for the illegal exploitation of black rhinos and elephants: poaching pays in Luangwa Valley, Zambia. Journal of Applied Ecology, 29, 388-401.

MOF (Ministry OF Forestry) (2007) Strategic and Action Plan for the Conservation of Rhinos in Indonesia 2007-2017. Rhino century program, Ministry of Forestry, Jakarta, Indonesia.

Mohd. Khan, M.K. (1987) Distribution and population of the Sumatran rhinoceros Dicerorhinus sumatrensis in Peninsular Malaysia. Rimba Indonesia, 21, 75-82.

Mond. Khan, M.K. (1989) Asian Rhinos: An Action Plan for Their Conservation. IUCN Species Survival Commission, Gland, Switzerland.

Mohd. Khan, M.K., Elagupillay, S.T. \& Zolkifli, Z. (1982) Species conservation priorities in the tropical rainforest of Peninsular Malaysia. In Species Conservation Priorities in the Forests of South-east Asia: Occasional Papers of the IUCN Species Survival Commission (eds R.A. Mittermeier \& R.W. Konstant), pp. 9-15. IUCN, Gland, Switzerland.

NST (New Sabah Times) (2008) Sumatran Rhino Rescued. New Sabah Times, 24 August 2008.

Payne, J. (1990) The Distribution and Status of the Asian TwoHomed Rhinoceros (Dicerorhinus sumatrensis harrissoni) in Sabah, Malaysia. WWF-Malaysia, Kuala Lumpur, Malaysia.

Rabinowitz, A. (1995) Helping a species go extinct: the Sumatran rhino in Borneo. Conservation Biology, 9, 482-488.

Schaffer, N.E., Agil, M. \& Bosi, E. (2001) Utero-ovarian pathological complex of the Sumatran rhinoceros (Dicerorhinus sumatrensis). In Abstracts of the International Elephant and Rhino Research Symposium (eds H.M. Schwammer, T.J. Foose, M. Fouraker \& D. Olson), pp. 322. Vienna, Austria.

Stevens, W.E. (1968) The rare large mammals of Malaya. Malayan Nature Journal, 20, 1-17.

Talukdar, B.K., Crosbie, K., Ellis, S., Ramono, W.S., WilLiams, A.C. \& Sectionov (2009) Report on the Meeting for Conservation of Sumatran and Javan Rhino in South-East Asia. Asian Rhino Specialist Group, Guwahati, Assam, India.

TAN, C.L. (2003) Divided over Breeding Plan. Http://www.jphpk. gov.my/English/Novo3\%2018D.htm [accessed 14 April 2010].

Traill, L.W., Bradshaw, C.J.A. \& Brook, B.W. (2007) Minimum viable population size: a meta-analysis of 30 years of published estimates. Biological Conservation, 139, 159-166.

Uryu, Y., Purastuti, E.P., Laumonier, Y., Setiabudi, A. \& Stuwe, M. (2010) Sumatra Snapshots: 1985-2008-2023. The Past, Present, and Future of Sumatra's Forests and Wildife and What It Means for Our Climate. WWF-Indonesia Technical Report. Jakarta, Indonesia.

van Strien, N.J. (1974) Dicerorhinus sumatrensis (Fischer), the Sumatran or two-horned Asiatic rhinoceros: a study of literature. Mededelingen Landbouwhogeschool Wageningen, 74, 1-82.

van Strien, N.J. (1985) The Sumatran Rhinoceros (Fisher 1814) in the Gunung Leuser National Park, Sumatra, Indonesia: Its Distribution, Ecology and Conservation. Verlag Paul Perey, Hamburg, Germany.

Van Strien, N.J. (2001) Conservation programs for Sumatran and Javan rhino in Indonesia and Malaysia. In Abstracts of the International Elephant and Rhino Research Symposium (eds H.M. 
Schwammer, T.J. Foose, M. Fouraker \& D. Olson), Vienna, Austria.

YABI (Yayasan Badak Indonesia) (2009) Annual Report. Yayasan Badak Indonesia, Bogor, Indonesia.

Zainal Zahari, Z. (1995) Review of Sumatran rhinoceros (Dicerorhinus sumatrensis) population in Peninsular Malaysia. Journal of Wildlife and Parks, 14, 1-15.

\section{Biographical sketches}

Abdul Wahab Ahmad Zafir, Azlan Mohamed, Ching Fong Lau and Gopalasamy Reuben Clements have been involved in
WWF-Malaysia's rhinoceros monitoring and protection in Royal Belum, Peninsular Malaysia, and Raymond Alfred and Junaidi PAYNE currently lead the conservation efforts of WWF-Malaysia and BORA for D. sumatrensis, respectively, in Sabah. Dionysius Shankar Kumar SHarma is the Chief Executive Officer of WWFMalaysia and Amirtharaj Christy Williams is in charge of WWF's Asian Rhino conservation strategies. Senthival Nathan oversees the husbandry of captive D. sumatrensis in Sabah on behalf of the Government of Sabah through the Sabah Wildlife Department. Widodo S. Ramono leads Indonesian conservation efforts for D. sumatrensis as executive director of Yayasan Badak Indonesia in Sumatra. 